\title{
Historic-geographical and typo-morphological assessment of Lefke town, North Cyprus
}

\author{
Sanaz Nezhadmasoum, Nevter Zafer Comert \\ Department of Architecture. Eastern Mediterranean University. Famagusta. North Cyprus \\ E-mail: sanaz.nezhadmasoum@gmail.com,nzafer@gmail.com
}

\begin{abstract}
Morphological analysis in cities have been employed to conduct the research on the urban form and fabric of the place, that helps to determine the conservation plans or strategies of towns that reveal clues to their own history (Whithand,2001). Such analysis methods are a process that reviews the evolution and evaluation of towns throughout history. This paper focuses on, Conzen's and Caniggia's ideas, MRG Conzen's historic-geographical approaches (1968) on planning level and Caniggia's typo-morphological process (2001) on architectural level. Those methodologies help to understand the transformation procedure of different regions of city throughout the years and recovering how the city elements and urban hierarchy are interrelated. Additionally, the focus of this paper is to study the town's morphological transformations, regarding its spatial, geographical and historical combinations. Within this context, Geographical and historical surveys done on the whole town of Lefke, in northwest Cyprus, and a detailed explanation on the typo-morphological analyses of some particular regions will be given in this article. One of the significant character that makes the town unique is its historical background which lay down with an organic urban pattern from Ottoman period. Lefke town was first formed with a medieval character, and through centuries of functional and physical transformations, has been highly influenced by British extensions, which were either prearranged modifications affected by socio- natural, economic, and political situations, or instinctive and spontaneous changes. All these historical factors, along with its geographical features, make Lefke an interesting case to be studied with an urban typo-morphological approach.
\end{abstract}

Keywords: Historic-geographic approach, Typo-morphology, Urban form, Lefke town.

\section{Introduction}

The morphological study of city has central objective for the understanding of urban Form, creation and transformation processes, spatial structure and character of human settlements through an analysis of historical development processes. It is also trying to understand the organization of its various elements and structures in terms of their physical characteristics. In this essence, urban morphology is used as an important assessment tool or method in determining the change transformation processes of urban fabrics, making sense of the historical roots of spatial and functional structures and bringing them to the present day (Topçu 2012). This analysis takes into account the urban fabric is the result of an evolutionary process (Conzen 1960). Understanding the city as a dynamic space and habitat as human communities. Planners, architects, landscape architects and engineers must, seek to have a broad vision of urban patterns, particularly on how it works and is organized (Oliveira,2013).

As Conzen (1981) stated that the most morphological analysis is defined by three fundamental physical elements: buildings and 
their building pattern, plots and plot pattern, and streets and can be understood at different levels of resolution. Commonly, four are recognized, corresponding to the building/ lot, the street/block, the city and the region. Moudon, (1997) argues that "Urban form can only be understood historically since the elements of which it is comprised undergo continuous transformation and replacement" (Moudon, 1997).

Accordingly, this study aims to analyse Lefke's morphological characteristics, which have developed throughout many years, and try to explores urban morphology based on two pioneering morphological studies: Gianfranco Cannigia's theories of typo-morphological understanding, and the evolutionary insights of M.R.G. Conzen. Taking the Lefke town as a case study, seeks to understand the spatial structure and character of a city by identifying the patterns of its components and the process of its development. Therefore, this analysis, includes a historical framework, and also analyzing physical structures at different scales. According to Conzen in 1960, land use, building structure, plot pattern, and Street pattern are considered. Analysis of physical forms focuses on street patterns, plot patterns, and building patterns by comparing cartographic sources and historic maps (Carmona, 2003).

\section{Morphological Studies}

The development of urban morphology, which constituted a component of urban geography as a subject, contain and crosses several different disciplines like architecture, philosophy, archaeology, history, anthropology as well as ethnography. Urban Morphology studies dates back to the beginning of 19th with Schutler (1899) and developed started to practice more commonly at 20th century. Morphological studies have been practice with three different perspectives in British (extension of German), France and Italy. Starting in Germany with Schutler (1899) by considering geographical point of view, in France with Phillipe Paneria and Jean Castex and sociologist Jean-Charles De Paule (1972) considered architectural and sociological perspective. On the other hand, Durand (1780) in Italy study typo morphologic analysis by considering architectural conditions. Starting of morphological studied by above mentioned names, it became a theory by Saverio Muratori, the pioneer of Italian schools. Following C. Aymonino, A. Rossi and G. Caniggia, G. Cataldi and Stappa, morphological studies continued and developed by pioneer of British schools, MRG Conzen as well as J. Whitehand, Karl Kropf ve Gu., Oliveria.

MRG Conzen (1981), started his morphological studies by defining the elements of the town; which concerning the aspects; street and the connections within street pattern, plot and street-plot relationship, as well as the buildings and the layers which consider the buildings plans within the blocks. While mentioning the historical process of the town by using fringe belt, he analyses the land utilisation, building pattern and genetic plan unit in order to reach the townscape. In Conzen's approach, Initial work in the field focused on analyzing evolution and change in traditional urban space (Carmona, 2001). Conzen describes how the integration of landscapes affects the early development of urban morphology (Whitehand, 1987) and the contribution of Conzen is mainly on the use of town plans which provides a source for historical study of urban morphology (Sima \& Zhang, 2009). This kind of urban morphological study is from the geographic view and concentrates on how the elements of settlements shape the urban structure (Sima \& Zhang, 2009). There are several examples of this type of urban morphological researches. For instance, Conzen (1988) carried out a town plan analysis of Alnwick and Ludlow in UK, and Muratori (1960) made a topological study in Venice town.

In 1996, morphologists from different disciplines such as geography, architecture, sociology, history and planning established the International Seminar on Urban Form (ISUF), an organization that acknowledges the expansion of urban morphology as an emerging interdisciplinary field. ISUF aims to provide a platform for the exchange ideas, theories and information about projects among a wide range of readers (http://www.urbanform.org). 


\section{Methodology of the Study}

As mentioned above morphological studies deal with many discipline and different approaches as a result of the formation of disciplines. Those studies started with MRG Conzen with his work for Alnwick (1969) and Ludlow (1975). MRG Conzen defines townscape as the general appearance of the town landscape. Historical period during the development of the town considered as a major aspect in order to put forward overall image. Similarly, he defines the characteristic of the town by considering natural and man-made environment. Building type, land use and plan units are the elements which overlapped together in order to form the townscape (Conzen,1969,257). By overlapping those elements, morphological characteristics and character areas are re-joined. Accordingly building types examined and grouped based on to their periodical characteristics. Following that, functions on the selected site examined and generalized which are defined in order to find out how they create the land use pattern on macro scale. Finally, to analyze plan units, by analyzing the relationship of the parcels that buildings located and neighbouring parcels, street/square in the block are examined. At the end, it aims to figure out the general characteristic of area by using the morphological regions. Morphological regions are defined by overlapped of those three elements. Setting up the criteria by using morphological regions, for the areas which will be developed within the town is considered as the most important aspect of the mentioned method.

By matching the above-mentioned aspect urban morphological are defined. Townscape plays an important role in defining urban development areas as well as on developing strategic decisions by local authorities. The unified form and the differences of those form the others within the same system are defined morphological regions. By doing that, building types, land use and plan units are shown with their common aspects and each section mapped hierarchically. The juxtaposition of three plan elements gives the overall townscape. By doing his townscape analysis MRG Conzen (1988) studied in to four different ranks according to their hierarchic importance as shown on the list below.

Town center or historical core, Plan unit, and neighbourhood which characterized by the region Within this context, study aimed to extend MRG Conzen's townscape method to the Lefke which have the trace of multicultural aspects. As a result of that It is planned to suggest the sets of principles for the future developments as the goal of the study. While doing this study, building typology has been analysed in order to understand the street silhouette, the relationship between building and its components in order to find out the compatibility of the pattern. Addition to this this typological classification will help to understand the overall typological view in the townscape.

Addition to this analysis typological analysis has been followed by Gianfranco Cannigia, who developed the dynamics of urban form, shaped by its component types and their evolution, throughout its historical development. He called these dynamics a "typological process". Caniggia's basic concerns were the historical formations and transformations of these types, as well as the urban fabrics that resulted (LEVY A., 1997). He was interested in how typological processes linked to more general mechanisms of cultural transmission, from generation to generation. Caniggia's work focused on the conceptual and political basis of architectural design and composition. (Caniggia G., Maffeig.L. 2001). According to Caniggia methodology this paper deals with his concepts through three different headings: (a) building, (b) urban tissues and (c) settlement organism/urban organism.

\section{Study area: Lefke Town, Cyprus}

Lefke is an important example of middle age town in Cyprus which shelter of different several cultures. In orderly the town ruled by (MÖ 4000), It is obvious that Byzantines lived in this town. This was first found out when the Ayorgi church was converted to a mosque called Piri Pasha mosque. Byzentiness 


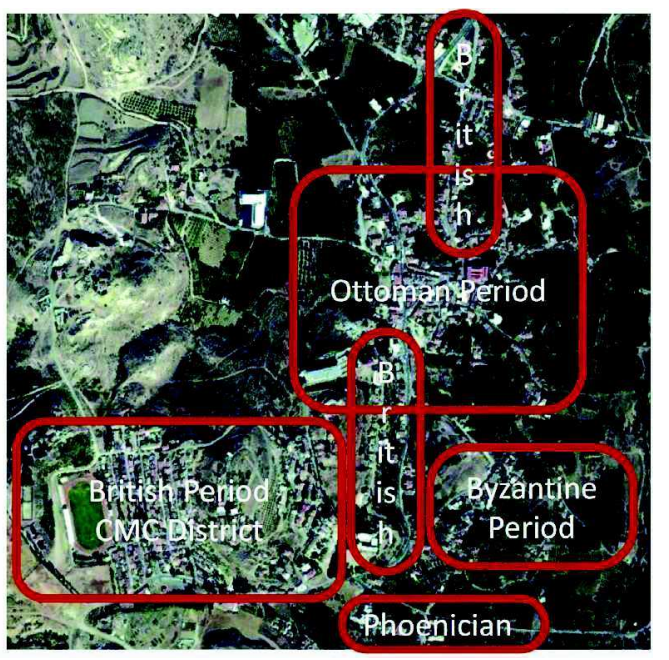

rigure 1.

Schematic periodical development of Lefke (Zafer Comert 2013)

lived in Cyprus between (789-1489), After the Byzantine period Ottoman conquer the island and at that time Lefke became one of the province of Ottomans' in Cyprus. When island hiring to British in 1571, Lefke became the most important industrial town at Cyprus, the reason for this is the establishment of Cyprus Mines Cooperation (C.M.C) until 1974. There are four different land uses in the town which, are gardens and agriculture with $38 \%$, dwellings $7 \%$, roads $16 \%$, and built environment $39 \%$ of Lefke (Iskan Bakanligi Sehir Planlama Dairesi:1989).

As seen on the schema on Figure 1 periodical development of Lefke started by Phoenicians settlement on the south of the cooper mines. Within this period beside the cooper mine, building the water channel can be seen as an evident of urbanization of the town (Ferlison,1986). During Byzantine period, the town started to shaped around st.Yorgi church by designing organic pathways. As it seen on Figure 2 during Ottoman period, town center moved and developed towards to north direction. Within this period khans, mosques, madrasah and many mansions located at town center while residential areas developed around that area (Figure 2). Lefke traditional core served as an important town for Ottomans with its narrow one-way streets and dens pattern. During British period, the use of copper mines cause settlement to moved towards to south and west with grid formation. By its designing with

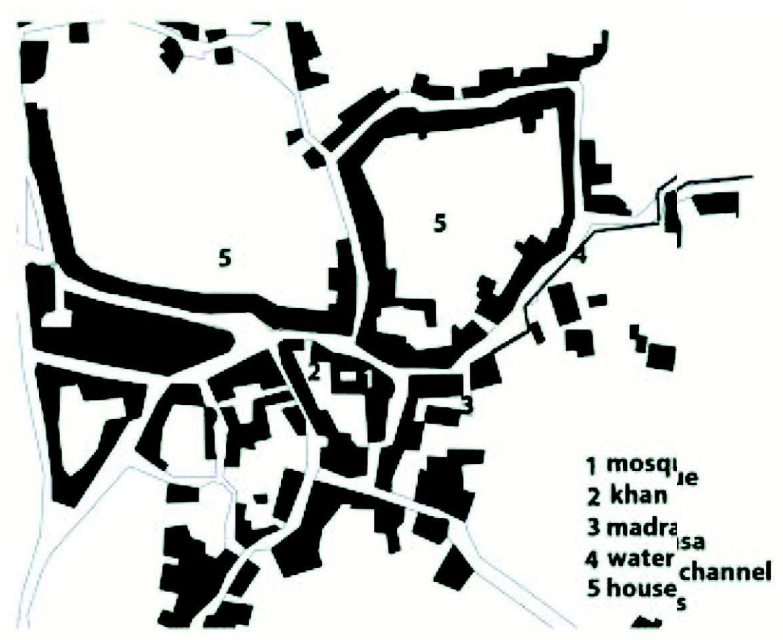

Figure 2.

Lefke Town Form During Ottoman and British Period (Comert \& Hoşkara 2013)

residential, social and recreational areas for copper mine workers, Settlement which located on west, shows the characteristics of suburb for Labours (Lavender,1962). Therefore, the center on the south hosted the residential areas, for people whom not working on the mines, beside the public building and spaces. Town pattern took its todays form by additions during British period (Lavender,1962). Land use of the city pattern have not been changed during the years, still town center which has been shaped in ottoman perioud seen as mixed use area (commercial and leisure promisses also public and community promisses), and residential units are mainly in the north and CMC districts (Figure 3).

\section{Typo-morphological assessment}

Lefke has significant with its own characteristics, within this study morphological development of Lefke town has been analysed in terms of building typology, street character and morphological regions. As a case study, the focus will be in a specific part of city which contain the historic core with the residential area along the organic shape street pattern, water channel, and agricultural lands Figure 4.

In order to understand the building typology, three elements have been investigated for the selected area; Plan typology, façade typology and plot typology. 


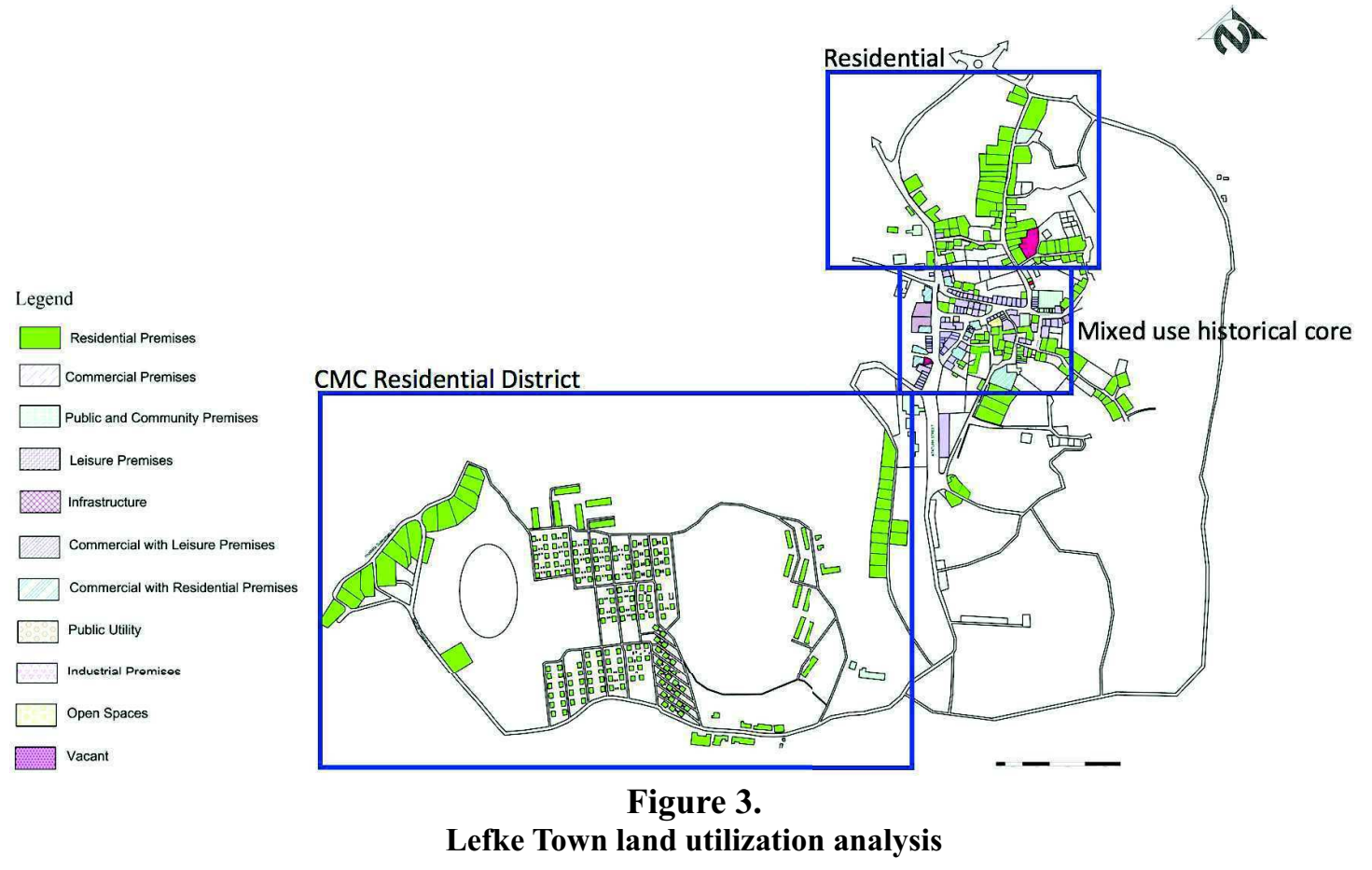

Plan typology analysis shows that this area has a basic plan from British till early modern periods, just some addition to the plans may have done according to their needs and requirement. Mostly it is composed of two living room, bedrooms, separate kitchen, and the toilets at the back. Houses has one main entrance called sofa, and two rooms are located surrounding this sofa. All those rooms face to the main street. Although the buildings dated back to Ottoman period, only two dwellings have been survived until today. When British come to the island they analysis the way of lifestyle of Cypriots and workers living units had been design according to this observation.

In CMC part, like traditional core all worker's kitchen and toilet is separated from the main unit which follows the characteristics of the city. But houses for engineer (usually they are British and American) all the functions designed in the same place (Figure 6). After 1960 Building plan is influenced by war and new city rules and regulations, more different plan could be seen in the contemporary construction. All the places are designed under one shelter whereas before generally kitchens and toilets are separated from the buildings in the garden.
Facade Typology analysis in this area shows that, residential building from British period in the Denis Efendi Street, are one story buildings which have got a pitched roof, windows and door ratios are 1.2 in large size and on the row, that is same with most of the other residential British building in the whole city, but as an exception there are two story's building from British period that has smaller windows in the first floor with ratio 1.1 and larger one in second floor with ratio 1.2. From elected period (1960-1970) in the same street you can see different size of windows with mostly 1.1 ratio and doors dimensions are same, and they are located in the middle. In the commercial part of the site again all of the buildings are belongs to the British period, they have large doors in booth 1.1 and 1.2 ratios and just two window with ratio 1.1.5 and the other one 1.2. Building's door and windows from TRNC and contemporary periods are almost different according to the size and ratio, different size and ratio in one building could be seen. While considering the facade, the typologies of elected buildings are more different than others and it is not fit to the context, different windows size and façade characteristic create this disparity (Figure 5).

"Conzen emphasized the plots and their plot pattern and the building arrangement 


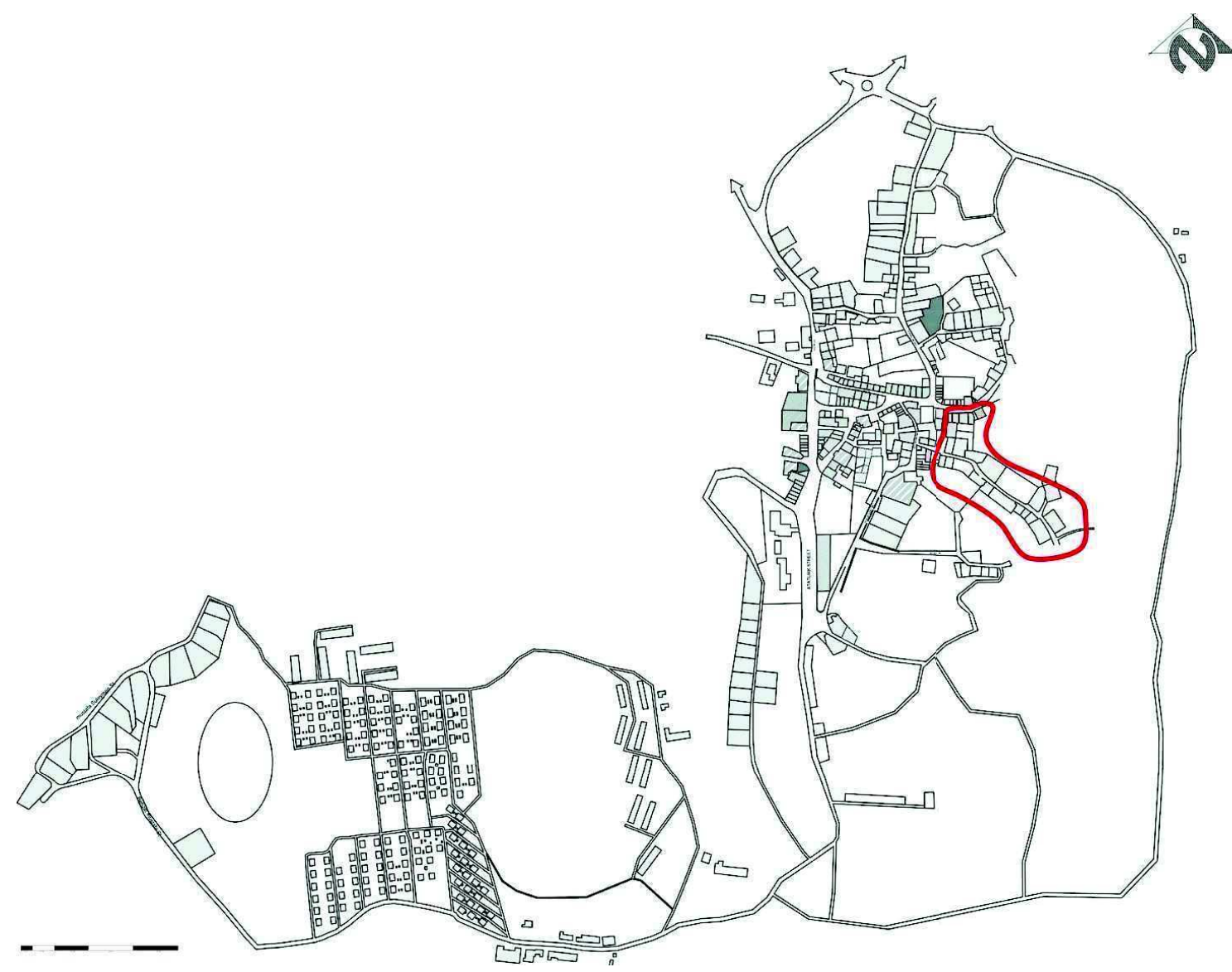

Figure 4.

Location of the selected area in Lefke Historic Town Center

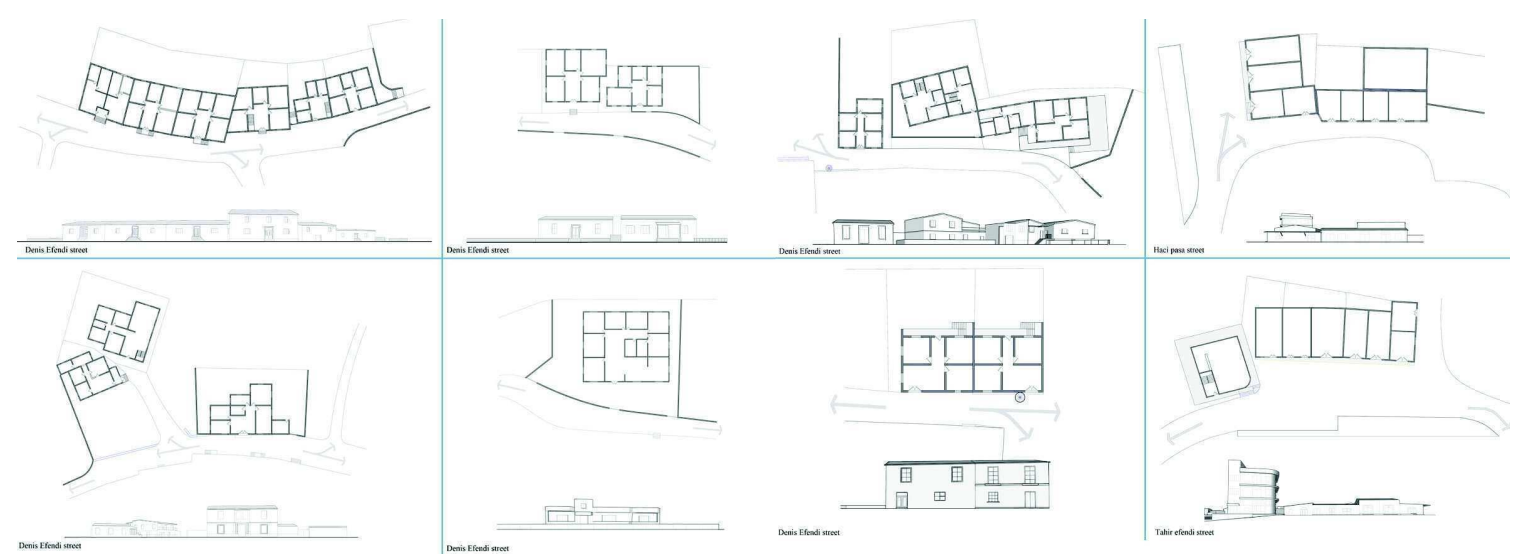

Figure 5.

Facade Typology of selected area in Lefke Historic Town Center

within these patterns for the plot typology analysis". As observed on the site plan, in the commercial premises part mostly plots has small and medium rectangular shapes with the ratio 1.2 and in the street corners 1.3. There are also houses with the rectangular shape with the ratio 1.2 . On the other hand, the plot typology in the Denis effendi street is different, most of the house's plot shapes are bigger and irregular, instead of two small square shape with empty plot between them and two big rectangular shape with the ratio 1.2. Also as an exception in this analysis there is L shape plot in the middle of commercial plots, as a result it could be consider plot divisions of the area as an organic plot pattern together with the agricultural pots 
between them (Figure 6). As seen in traditional core mostly plot typology carries the same character with its rectangular formation. Especially at commercial district plots are reputed with the same proportion as seen in Figure 6.

On the other hand, CMC part as observed on the site plan, the plot division is only performed on the engineers' and foremen's houses. therefore, the plot typology of the foremen's houses is irregular; more or less, their ratios are similar (1.2). Another plot typology is observed with the workers housing district: all the plots show the characteristics of amalgamated typology resulting in a rectangular big block (ratio: 1.3/1.4), which then has several housesgenerally 8-in the same block. Within these blocks, every two houses share a common toilet (Figure 6).

According to the observation from the site, and by considering the street and plot relation, it can be determined that British houses are mainly developed along the street with their front façade attached to the street, defining the street pattern. There also some detached building with the small front yard and private garden from early modern and contemporary periods, with the bigger plot size.

Pertinent and elevated

Figure 6. Typo-morphological analysis of the selected area in Lefke Historic Town Center

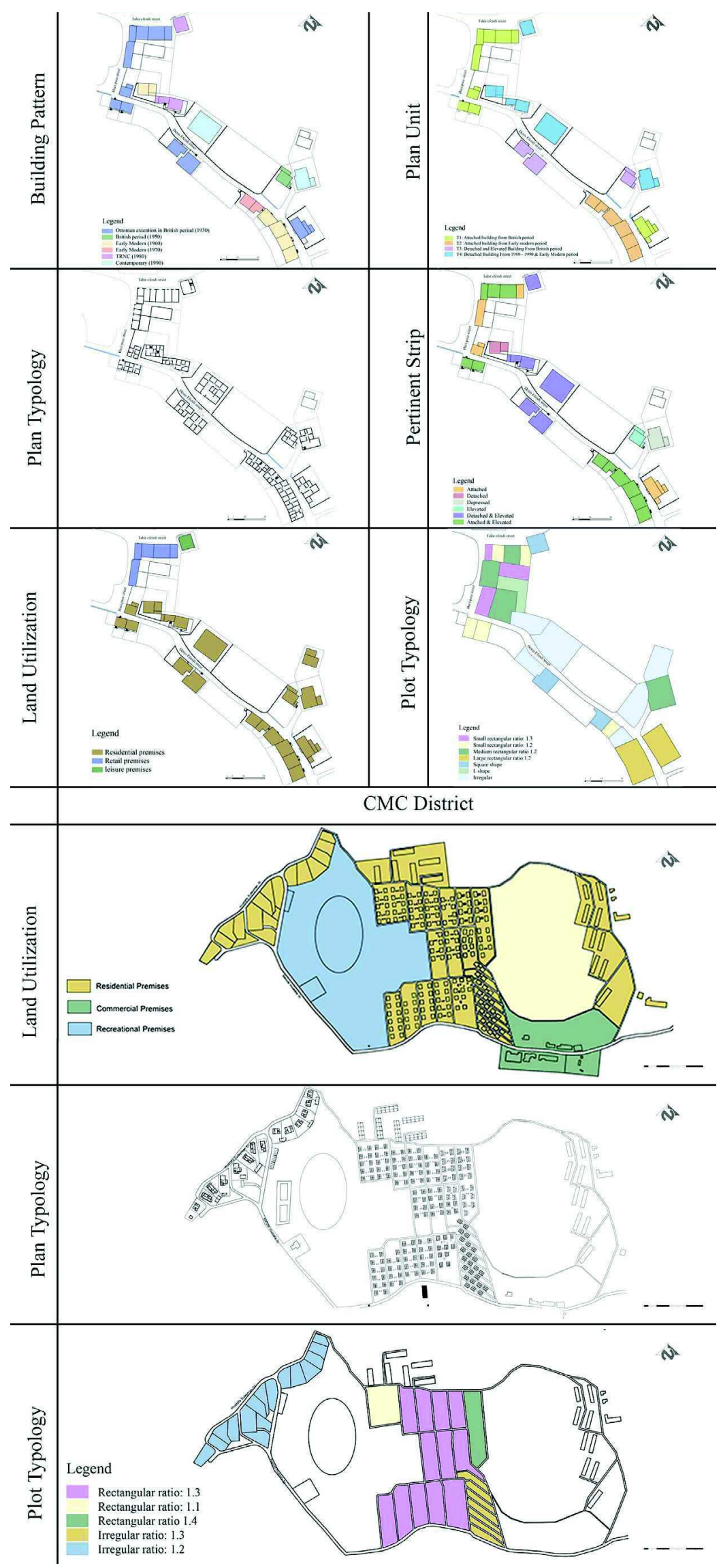




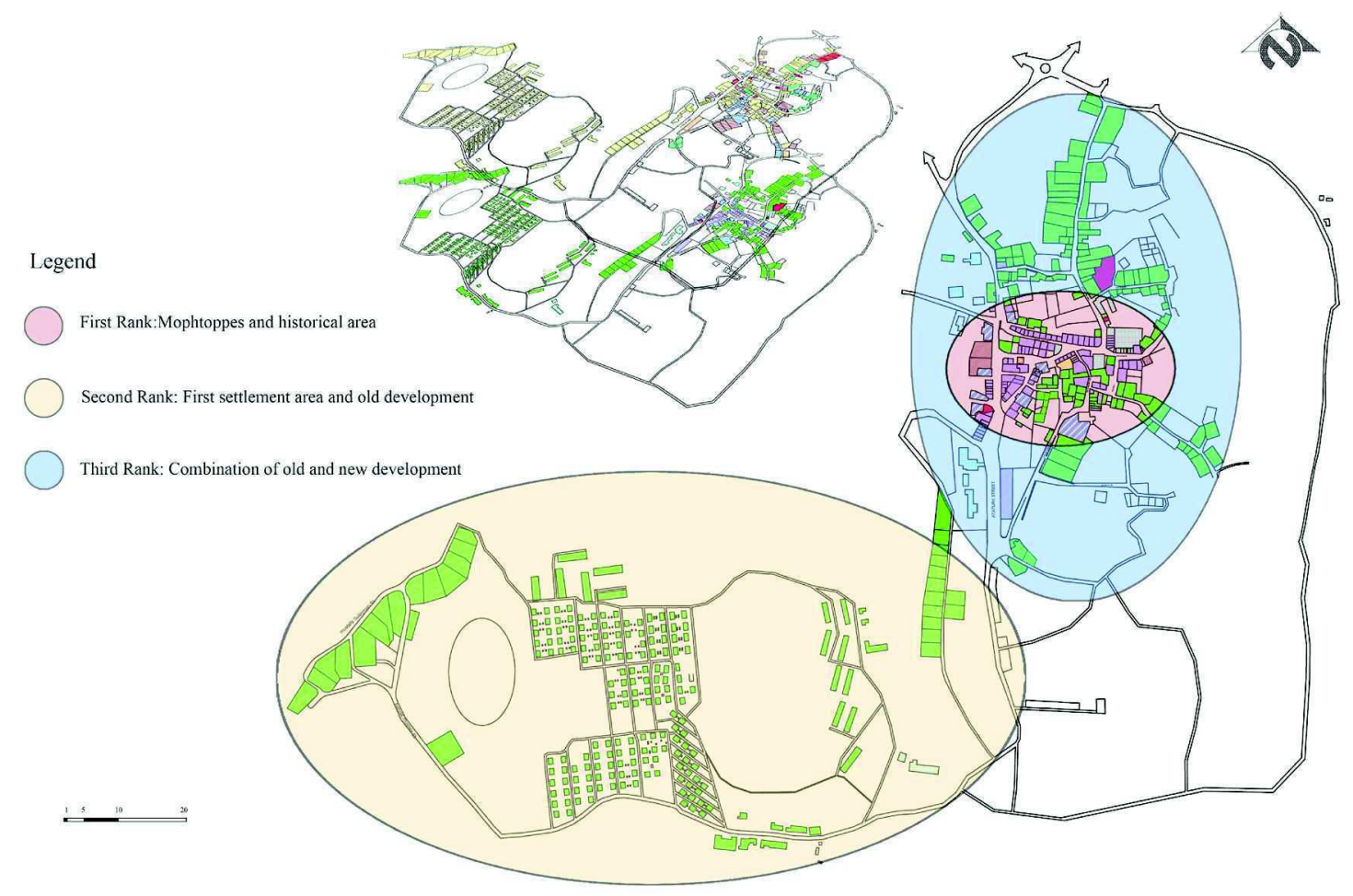

Figure 7.

Lefke Town Morphological region analysis

character which create a different pertinent strip typology in the site it could be a result of topography, With the influence of the topography, Buildings are mostly elevated, and in the sloppy part of the site approximately one meters higher than the road, even the attached buildings which are not elevated from the street have level differences, that called "su basman" in Turkish, in order to prevent from the rain water. Also, another significant factor that affect the street pattern not only in this area but in the whole city is the water channel, the water is used for the agricultural purposes in the city (Figure 6).

Those water channel along the street makes the street character special especially at the historical core. It has been observed as an open channel system on Danis Efendi St. and some parts of Atatürk Street. Rest of them are covered with the sidewalks in 2000. On the other hand, CMC part street formation is totally different than the traditional core. Street pattern formed as a grid system and all the waste water from kitchen was carried with channels next to the street. All waste water channels carried on specific site for re use. But today all the channels are inactive because of the necessity of today life style. Sidewalks are lay along those channels.

\section{Townscape Analysis}

Plan unit, land utilization and building pattern are the main three factors which analysed in this study for understanding the town scape in this area. "Plan unit represents the relationship between building types, street characters and plots", Addition to this, position of the building in the plot and their relation with streets are analysed in order to figure out the plan unit. In the analysis, the area mostly divided to 15 plan units has been observed; Different plan units had been observed on the streets and avenues within Lefke traditional town pattern. Planning regulation, articles, and caps are the reason for that condition. Until 1948 buildings designed attached to each other with the same line of the main road. According to the new roads and buildings regulations after 1948 with cap96, the buildings within the town, including town center, had been built $5 \mathrm{~m}$ away from the 
road and $3 \mathrm{~m}$ away from the sides. Accordingly, different street patterns can be seen on the same street in relation to the buildings which built in different periods according to different regulations. For example, Danis Efendi plan unit is the British buildings attached to the street with the rectangular plot shape, detached and elevated with irregular and square plot shape which includes three buildings, attached and elevated building from early modern with the back yard, And the detached buildings from contemporary and early modern which placed in the middle of large plots. As a result of that it is not possible to see a homogenous plan unit within the town. On the other hand, CMC part also shows another plan unit type because of the amalgamation of the plots and buildings locations, positions and building style.

From following the historical process of whole lefke town, it is clear that the town center had preserved its commercial function up todays. It had been observed that only three building demolished and changed their function to residential buildings. Moreover, the public buildings are located at the end of commercial area as a border between residential and commercial areas. Finally, the Educational district is located adjacent to residential area. According to Conzen land utilization classification, selected area also contains three different types of land utilization. Commercial premises in Haci pasa and Tahir Efendi street, where its connect the east part to the center of the city. In the west side of the commercial area, Mosque is located in the centre of the traditional core in front of municipality and marketing (bazaar) area, and leisure premises in the ground floor of tow story residential building as a coffee, restaurant. Residential premises, includes all of the building in Denis effendi street, located in the eastern part of the historical core (Figure 6).

Addition to this, the establishment of CMC district sub center has been created a different land use in this district, which is also contains three different types of land utilisation; includes housing districts, commercial districts and recreational district. The recreation district is an area that has never been mentioned by Conzen in his land utilisation classification.

As mentioned, building pattern studies of
Lefke town shows the historical formations and transformations of the city, and examining its historical development. Lefke were developed through various historical periods which creates variety in the city pattern, Traditional core carries its significant character where shows the impact of British period but building styles are recopied from the Ottoman style. Extension of the traditional zone is signifying with its modern period development and this formation starts with extension of Atatürk street and Küçük İzzet St. In the selected area majority of the buildings had constructed in British period between 1930 - 1950, mostly with the Ottoman extension, after that eclectic type or early modern period between 1960-70 constitute a significant amount, From Turkish Republic of North Cyprus and contemporary also a few buildings have been found. This variation in Building pattern does not terminate too much changes in the plans till 1980. It demonstrates that they follow the previous plan type, just some additions may have been added, also after 1960 some changes have been done, especially in dimensions of pitch roofs, because of the rules and regulation (Figure 6).

\section{Morphological region}

In order to analysing the morphological region in the lefke city the whole city map have been considered and analysed, in this analysis three criteria's; building pattern, land utilization and the plan unit have been ranked and overlapped. The results demonstrate 3 certain ranks: in the first rank, the initial urban nuclei with the historical buildings which are located in the city center and continue to the west part with more commercial and public facilities and activities, create a unique characteristic for the city and make it different than other parts. The second rank includes the first settlement area, which contains CMC housing district and mostly British housing area in the south part of urban nuclei. Combination of old and new buildings ranked third and mostly take place in the north and center part of the city, because of less significant values than the other and its fragmentation around the city. 


\section{Conclusion}

Morphological analysis method By MRG Conzen firstly used in UK, then in Japan and China and applied on different geographies and cultures later. The mentioned method has been continued to use and applied to different cities all around the world in order to understand the evolution of the urban form. Accordingly, the same mentioned method has been applied to Lefke Traditional Town Center, as one of the four historic urban quarter in Northern Cyprus which has a traditional urban pattern that shaped by a medieval character and have been significantly impacted by British influences.

The historical assessment area of Lefke shows the traces of the ottoman culture, and the identity of the places strongly carries ottoman influence. The organic pattern of the city has been also influenced by the existence of topography, agricultural land and water channel, Despite, within its overall organic urban pattern, there are well-scaled narrow streets, a number of public buildings and irregularly shaped public spaces at the intersection of streets and/or in front of public buildings.

According to the result of the applied method, Traditional dwellings and settlement pattern of Lefke have been investigated throughout the morphological analysis and ranking the analysis revealed the different characteristic of the city pattern, that defined the valuable parts of the city which needs to be preserve and protect. Also, the investigation has shown that Lefke has an urban form and place identity which has relation with its physical factors and historical development. An urgent conservation and rehabilitation action, with good urban management, is needed in this area. Any intervention for the purposes of repair, renovation and rehabilitation in the district should have the goal of conserving the typological and morphological characteristics of the district. Morphological studies are important in terms of development, perceiving and sustainability of town form. Urban forms are identified by using the morphological analysis and it gives the planning and conservation strategies for the future. The proposal for the future of the study is;
-To understand how the urban form will be conserve and sustain in the future

-To put the principles for further development

-To define the sustainable morphological criteria

-To sustain the urban form for future

\section{References}

Carmona, M., Heath, T., Oc, T., \& Tiesdell, S. (2003). Public spaces. Urban spaces. The Dimension of Urban Design, 1, 46-47.

Caniggia, G., \& Maffei, G. L. (2001). Architectural composition and building typology: interpreting basic building (Vol. 176). Alinea Editrice.

Castexs, (2004), Urban Forms-The Death and Life of the Urban Blocks, Architectural Press, UK.

Conzen, M. R. G. (1969). Alnwick, Northumberland: a study in town-plan analysis. Institute of British Geographers.

Conzen M.R.G, (1975), Geography and Townscape in First German-English Symposium on Applied Geography,ed Harald Uhlig and Cay Linau, vol 35,1975, pp. $95-102$

Conzen, M. R. G. (1988). Morphogenesis, morphological regions and secular human agency in the historic townscape, as exemplified by Ludlow. Urban historical geography: recent progress in Britain and Germany, 253-72.

Conzen, M. R. G. (2004). Thinking about urban form: papers on urban morphology, 1932-1998. Peter Lang.

Conzen, M. P., Herbert, D., \& Johnston, R. J. (1981). The American urban system in the nineteenth century.

Cömert, N. Z., \& Hoskara, S. O. (2013). A TYPO-MORPHOLOGICAL STUDY: THE CMC INDUSTRIAL MASS HOUSING DISTRICT, LEFKE, NORTHERN CYPRUS. Open House International, 38(2), 16-30.

Ferlison İ.,(1986), Step by step Lefke and its district, unpublished graduation thesis, Nicosia, 22-25.

Lavender, D. S. (1962). The Story of Cyprus Mines Corporation. Huntington Library. 
Oliveira, V. (2013). Morpho: a methodology for assessing urban form. Urban Morphology, 17(1), 21-33.

Oliveira, V. (2013). The study of urban form: reflections on national reviews. Urban Morphology, 17(2), 85-92.

Moudon, A. V. (1997). Urban morphology as an emerging interdisciplinary field. Urban morphology, 1(1), 3-10.

Topcu, M., \& Kubat, A. S. (2012). Old and new city: morphological analysis of Antakya. In Eighth International Space Syntax Symposium.

Whitehand, J. W. R. (1987). MRG Conzen and the intellectual parentage of urban morphology. Planning History Bulletin, 9(2), 35-41.

Zafer, N. (1999), Lefke Deniz İle Ağaç Kokusunun Karıştığı bir yerleşim yeri, in Dağlı,U.U. (ed.) Kıbrıs Sokaklarinda mimariye, yaşama ve cevreye dair. 76-83, Isik Kitapevi. 